\title{
Disturbance intensity, disturbance extent and ocean climate modulate kelp forest understory communities
}

\author{
Thomas Wernberg ${ }^{1,2, *}$, Marine Couraudon-Réale ${ }^{1}$, Fernando Tuya ${ }^{3}$, \\ Mads Thomsen ${ }^{1,4}$ \\ ${ }^{1}$ UWA Oceans Institute \& School of Biological Sciences, University of Western Australia, Crawley, WA 6009, Australia \\ ${ }^{2}$ Department of Science and Environment (DSE), Roskilde University, Roskilde 4000, Denmark \\ ${ }^{3}$ Grupo en Biodiversidad y Conservación, IU-ECOAQUA, Universidad de Las Palmas de Gran Canaria, \\ Las Palmas 35010, Spain \\ ${ }^{4}$ Marine Ecology Research Group and Centre for Integrative Ecology, School of Biological Sciences, \\ University of Canterbury, Christchurch 8041, New Zealand
}

\begin{abstract}
Disturbances often control community structure by removing large dominant species, allowing new species to colonize. Disturbances vary in intensity and extent, and their effects on resident communities can depend on local environmental conditions. We tested the effects of disturbance intensity and extent on different functional groups of understory species in kelp forests at 4 locations along an ocean climate gradient in Western Australia. We hypothesized that, compared to intact canopies, increasing disturbance intensities (50 and $100 \%$ of kelp removal) and extents $(2,4$ and $8 \mathrm{~m}$ diameter) would promote light-dependent competitors (turf, foliose, articulated coralline and fucoid seaweeds) at the expense of less light-dependent functional groups (invertebrates and encrusting seaweeds). We also hypothesized that these effects would be most pronounced at warmer relative to cooler locations, where metabolic and ecological rates are faster. The first hypothesis was supported; light-dependent understory groups (turfs, in particular) increased, while less light-dependent groups (crusts in particular) decreased with increasing disturbance regimes. However, the second hypothesis was not supported; even though understory communities differed between locations and turf covers were highest at the warmest location, we found no significant interactions between locations and disturbance regimes. Importantly, our results revealed that even small-scale partial canopy loss can have significant effects on kelpassociated communities. The implied community-wide, density-dependent effects have implications for the management and conservation of kelp forests, because restoration of ecological functions must also consider the density of kelp forests, not simply their presence or absence.
\end{abstract}

KEY WORDS: Disturbance - Facilitation - Ocean climate - Western Australia - Temperate reefs . Functional groups $\cdot$ Ecklonia radiata

\section{INTRODUCTION}

Natural and human-mediated disturbances modify the structure and functioning of communities and ecosystems (Grime 1977, Diaz-Pulido et al. 2009, Wernberg et al. 2013a). Discrete weather events,

\footnotetext{
*Corresponding author: thomas.wernberg@uwa.edu.au
}

such as storms or heatwaves, are important drivers of disturbances in marine systems, where they are expected to increase in frequency and severity under most future climate change scenarios (IPCC 2014, Cai et al. 2015, Oliver et al. 2019). The response of communities and ecosystems to disturbances de- 
pends on characteristics of the events, such as the type, frequency, intensity and extent of disturbance (McCabe \& Gotelli 2000, Sousa 2001, BenedettiCecchi et al. 2006, Vaselli et al. 2008, Thakur et al. 2014, Čada et al. 2016). At the same time, disturbance effects can also vary dramatically according to characteristics independent of the events, such as the specific local biotic and abiotic context (Dudgeon \& Petraitis 2001, Wernberg \& Connell 2008, Wernberg et al. 2010, Kramer et al. 2014).

Disturbance intensity (proportion destroyed) and extent (scale of destruction) can be particularly important drivers of changes in the abundance of individuals, species richness and diversity (Thrush \& Dayton 2002, Norkko et al. 2006, Granek \& Ruttenberg 2008, Flukes et al. 2014, Wilby et al. 2015, Bell et al. 2016, Cox et al. 2016). While there are numerous studies documenting the individual effects of either disturbance intensity or extent across a wide range of ecosystems (e.g. Sousa 1984, Englund \& Cooper 2003, Schiel \& Lilley 2011), few studies have tested their combined effects on natural communities (e.g. Wernberg \& Connell 2008, Tuya et al. 2009). Indeed, most disturbance experiments have only simulated severe pulse perturbations that compare completely denuded areas with undisturbed control plots (e.g. Lison de Loma et al. 2000, Edgar et al. 2004, Granek \& Ruttenberg 2008, Ling 2008). Similarly, most experiments testing the role of environmental conditions on disturbance effects compare only 2 levels, such as sheltered and exposed locations (e.g. Wernberg \& Connell 2008). However, in natural systems, disturbances manifest as gradients of intensities and extents across gradients in environmental conditions (Kennelly 1987a, Denny 1995), potentially resulting in interactions and non-linear threshold effects (Petraitis \& Latham 1999, Pascual \& Guichard 2005, Schiel \& Lilley 2007, Layton et al. 2019) that binary, single-factor experiments cannot identify. For example, disturbance extent and intensity could produce non-linear interactions through their effects on effective dispersal distance and survival, respectively, of colonizing species or their predators (e.g. Farrell 1989, Petraitis \& Dudgeon 1999, Gagnon et al. 2003, Layton et al. 2019). Environmental gradients, such as wave exposure or temperature, could add a third dimension of potential interaction by affecting metabolic and ecological rates (e.g. dispersal, recruitment, growth, reproduction, mortality) differentially, often in non-linear ways (e.g. Gaylord et al. 2002, Wernberg et al. 2010, Kordas et al. 2011).
Kelp (Ecklonia radiata) forests dominate Australia's Great Southern Reef, including southwestern Australia (Bennett et al. 2016, Wernberg et al. 2019), where they support diverse fish, invertebrate and seaweed communities (Vanderklift \& Kendrick 2004, Coleman et al. 2007, Tuya et al. 2008, 2010, Smale \& Wernberg 2014). These kelp forests promote and inhibit other species found in or around them by controlling processes such as frond abrasion, light penetration, sedimentation, water motion, habitat and food provisioning (Kennelly 1987b, Toohey et al. 2004, Anderson et al. 2005, Wernberg et al. 2005, Irving \& Connell 2006a, Layton et al. 2019). Since kelps have a strong influence on their associated understory communities, disturbances to canopies are likely to affect the entire kelp ecosystem (Ling 2008, Byrnes et al. 2011, Wernberg et al. 2016a, Layton et al. 2019).

In this study, we tested the interactive effects of gradients in disturbance intensity, extent and varying ocean climate regimes on kelp forest understory communities. We hypothesized that intensity (50 and 100\% kelp removal) and extent (unmanipulated controls, and 2, 4 and $8 \mathrm{~m}$ diameter circular kelp removals) of disturbances would promote lightdependent functional groups (turf, foliose, articulated coralline and fucoid seaweeds), while suppressing understory organisms that are less light-dependent (invertebrates and encrusting seaweeds). We also hypothesized that these effects would be more pronounced at warmer locations, where metabolic and ecological rates are higher (Kordas et al. 2011, Wernberg et al. 2016b).

\section{MATERIALS AND METHODS}

\subsection{Study locations and experimental design}

Our study took place along the southwest coast of Western Australia. This stretch of coast runs north-south and is characterised by a gradual $2-3^{\circ} \mathrm{C}$ increase in ocean temperature from Hamelin Bay $\left(\mathrm{Ham}_{i} 34.2^{\circ} \mathrm{S}\right)$ in the south to Kalbarri in the north $\left(\mathrm{Kal}_{;} 27.7^{\circ} \mathrm{S}\right)$ (Smale \& Wernberg 2009). Subtidal lime and sandstone reefs are found all along this coastline. These reefs have a diverse algal flora, dominated, in terms of cover and biomass, by the kelp Ecklonia radiata (Wernberg et al. 2011). We used a hierarchical design, where identical experiments were set up at 4 locations across this ocean climate gradient: Hamelin Bay $\left(\mathrm{Ham}_{;} 34.2^{\circ} \mathrm{S}\right)$, Marmion (Mar; $\left.31.8^{\circ} \mathrm{S}\right)$, Jurien Bay (Jur; $30.3^{\circ} \mathrm{S}$ ) and Kalbarri 
$\left(\mathrm{Kal}_{;} 27.7^{\circ} \mathrm{S}\right)$. These locations are evenly spaced by $\sim 2^{\circ}$ of latitude ( $200-300 \mathrm{~km}$; Fig. 1) and encompass a latitudinal gradient in ocean temperature, which is not confounded or interrupted by other environmental drivers such as upwelling, wave exposure or depth (Smale \& Wernberg 2009, Wernberg et al. 2010) (Fig. 1).

Three reefs, separated by a minimum of $1 \mathrm{~km}$, were sampled within each location. At each reef, there were 2 replicated plots of each experimental treatment; all plots were separated by at least $4 \mathrm{~m}$ from edge to edge. All plots were set up on reef flats, between 8 and $12 \mathrm{~m}$ depth, in areas covered by $70-90 \%$ E. radiata. We were limited to 2 replicate plots per treatment because our plots were very large (up to $50.2 \mathrm{~m}^{2}$, see below). Since the plots were scattered across a large reef area, and some plots were hard to visually relocate (partial removal and recovered clearings), we unfortunately were unable to resample all plots within the available dive time restrictions. At least 1 plot per treatment was relocated on each reef and, consequently, we analysed disturbance effects on reef-averaged treatments (i.e. $\mathrm{n}=3$ reefs location $\left.^{-1}\right)$. This decision reflects our scope of inference, because we were concerned with broad-scale, fixedfactor effects across latitudes and not small-scale, random variation across reefs within locations.

\subsection{Experimental treatments}

Canopy algae were removed in orthogonal treatments combining 2 intensities (partial vs. complete: $\sim 50$ vs. $100 \%$ canopy cover removal) and 4 extents (control, 2, 4 and $8 \mathrm{~m}$ of circular diameter; 0, 3.1, 12.5 and $50.4 \mathrm{~m}^{2}$, respectively). This design implies that we set up 2 identical types of control plots, 2 untouched 'control-partial' plots for partial canopy removal controls and 2 untouched 'controlcomplete' plots for the complete canopy removal controls. These plots were treated as separate control plots in the factorial statistical analysis (as Cp and $\mathrm{Cc}_{\mathrm{c}}$, respectively), but, because they represent the same ecological condition (untouched canopy), they were pooled in the graphs. The implemented treatments represent ecologically relevant and realistic disturbance regimes in contemporary Australian kelp forests, with the $8 \mathrm{~m}$ diameter extent $\left(50.4 \mathrm{~m}^{2}\right)$ representing extreme wave-induced disturbances (Kennelly 1987a, Connell \& Irving 2008, Wernberg \& Connell 2008, de Bettignies et al. 2015). Canopy algae were removed manually by pulling each kelp from the reef, mimicking natural canopy loss from waves. Treatments were implemented in late austral summer to early autumn (March-April 2006) to coincide with the season of

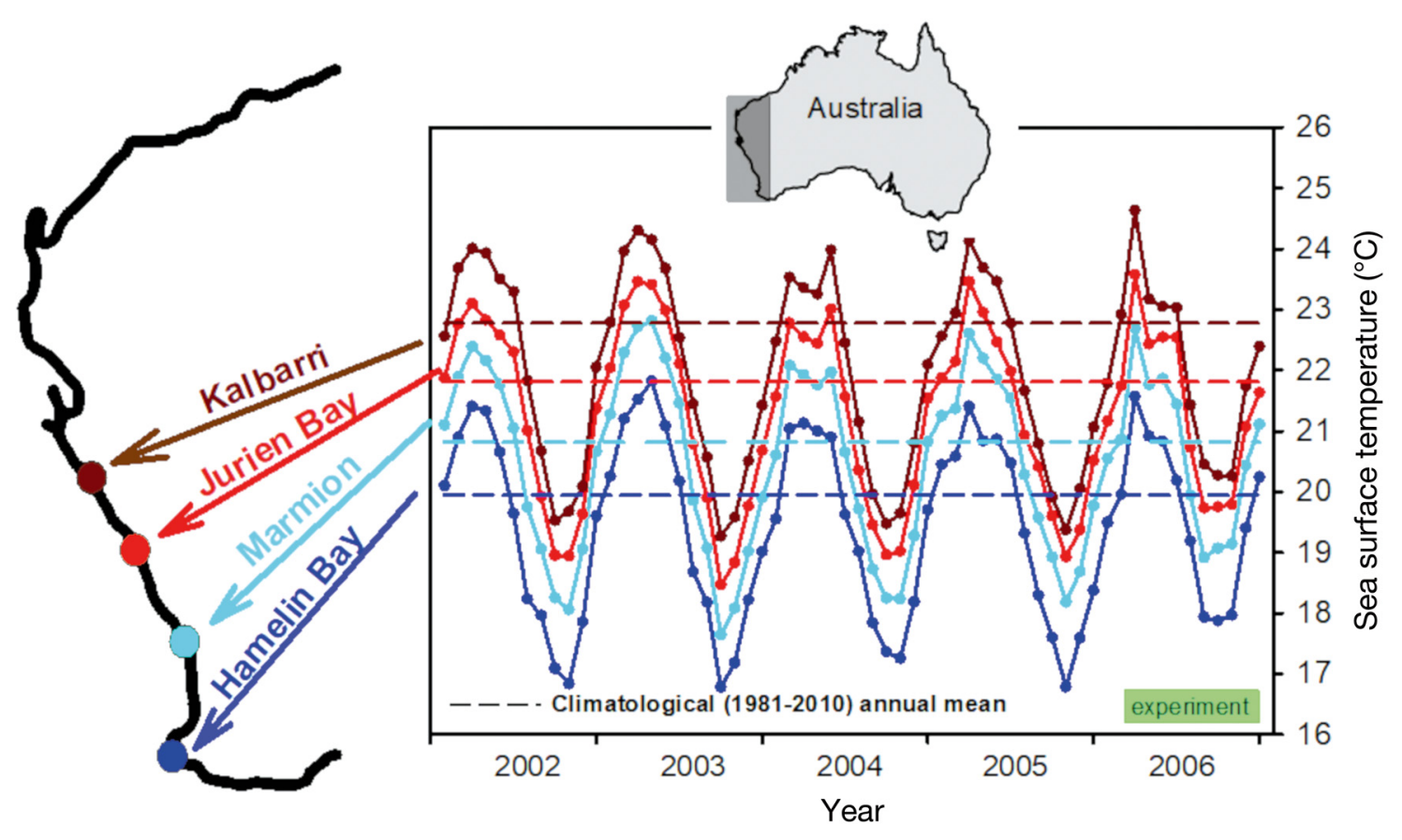

Fig. 1. The Australian west coast showing our 4 experimental locations: Hamelin Bay $\left(34.2^{\circ} \mathrm{S}\right)$, Marmion $\left(31.8^{\circ} \mathrm{S}\right)$, Jurien Bay $\left(30.3^{\circ} \mathrm{S}\right)$ and Kalbarri $\left(27.7^{\circ} \mathrm{S}\right)$ and corresponding sea surface temperatures in the years prior to and during the experiment. Annual means of sea surface temperatures are represented with dashed lines for each location. We used monthly NOAA Optimum Interpolation Sea Surface Temperature Version 2 data (https://psl.noaa.gov/data/gridded/data.noaa.oisst.v2.html) 
maximum natural canopy loss (Kirkman 1989, de Bettignies et al. 2013) and minimum understory development (Wernberg \& Goldberg 2008). The experiment was set up and sampled out of spatial order (Jur, Ham, Mar, Kal) to avoid confounding the latitudinal gradient with time of experimental initialisation and sampling.

\subsection{Sampling}

The percent cover of organisms was visually estimated for each of 6 common types of functional groups (Table 1), 8 mo after plots were established, within 3 replicate $0.25 \times 0.25 \mathrm{~m}$ quadrats (Wernberg et al. 2003) haphazardly positioned within the centre $1 \mathrm{~m}$ radius of each plot. This duration captured the main seasonal dynamics of Australian kelp forests (Wernberg \& Goldberg 2008) and was sufficient for species to respond, and generate detectable community-level responses, to physical disturbances (Wernberg \& Connell 2008). Moreover, in this system, seasonal variation in community structure (Wernberg \& Goldberg 2008) is much smaller than spatial variation between regions (Wernberg et al. 2003, Smale et al. 2010). Consequently, consistent with our main focus on understanding differences between climate regimes, this sampling design emphasised effects of locations across latitudes as a proxy for differences in environmental conditions, but did not allow inferences about trajectories of recovery or long-term effects. Visual estimates of cover are equal, or even superior, to point-intercept methods, especially in layered communities (Benedetti-Cecchi et al. 1996). In addition, all data collections were made by the same SCUBA diver (T. Wernberg), minimising potential observer bias (Benedetti-Cecchi et al. 1996).

\subsection{Statistical analyses}

The percent cover of each functional group was analysed by factorial ANOVA to test for significant effects among locations ('Lo'; fixed factor, 4 levels: Ham, Mar, Jur, Kal), disturbance extent ('Ex'; fixed factor, 4 levels: control, 2, 4 and $8 \mathrm{~m}$ ), and disturbance intensity ('In'; fixed factor, 2 levels: partial and complete canopy removal). The design also included 3 a priori contrasts comparing control plots to all disturbed plots (contrast 1: Cp, Cc vs. 2, 4 and $8 \mathrm{~m}$ ) and disturbed plots of increasing size (contrast 2: 2 vs. 4 and $8 \mathrm{~m}$; contrast 3: 2 and $4 \mathrm{~m}$ vs. $8 \mathrm{~m}$ ).

Factorial ANOVAs were analysed with the PERMANOVA package in PRIMER v.6 with 9999 permutations of the raw data. We used Euclidean distance matrices for percent cover of each functional group and Bray-Curtis dissimilarity matrices for multivariate community structure. Initially, all data were square root transformed to down-weight the prevalence of abundant groups. A posteriori pairwise comparisons were used to resolve differences between treatment levels following significant effects of fixed factors. We also tested for homogeneity in dispersion for each functional group and the multivariate community structure, using the PERMDISP routine. Principal coordinates ordination (PCO) was performed to visualise similarities in community structure according to disturbance regimes (= fixed factors). The PRIMER package and analyses are described in detail in Anderson et al. (2008).

\section{RESULTS}

The multivariate structure of the understory community differed dramatically among locations (Lo, $\mathrm{p}=0.0001$; Table 2, pairwise tests: Ham $\neq$ Mar $\neq$ Jur $\neq$

Table 1. Functional groups of understory organisms, including the most common taxa found in the study area on the southwest coast of Western Australia

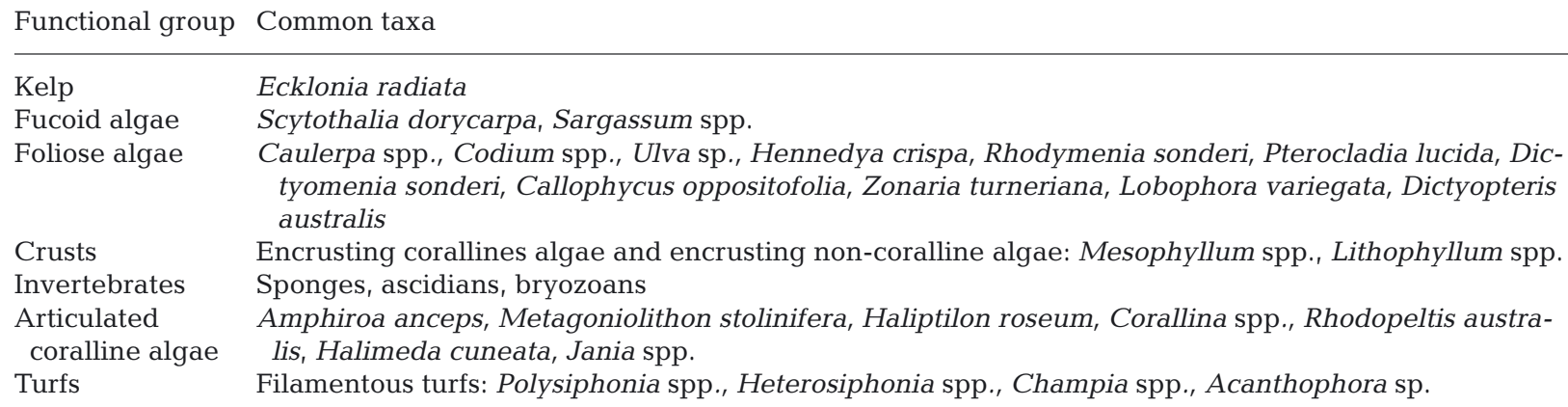
tyomenia sonderi, Callophycus oppositofolia, Zonaria turneriana, Lobophora variegata, Dictyopteris australis

Crusts Encrusting corallines algae and encrusting non-coralline algae: Mesophyllum spp., Lithophyllum spp. Invertebrates Sponges, ascidians, bryozoans

Articulated Amphiroa anceps, Metagoniolithon stolinifera, Haliptilon roseum, Corallina spp., Rhodopeltis austracoralline algae lis, Halimeda cuneata, Jania spp.

Turfs Filamentous turfs: Polysiphonia spp., Heterosiphonia spp., Champia spp., Acanthophora sp. 
Kal). At the same time, after $8 \mathrm{mo}$, there were strong effects of disturbance extent and intensity on understory communities (In and Ex, p = 0.0001, Ex $\times$ In, p = 0.0043 ; Table 2). At all locations, the community structure in disturbed plots $(2,4$ and $8 \mathrm{~m})$ differed from controls (Table 2). There were, however, no differences in understory community structure between disturbances of varying extent for both partial and complete canopy clearings (pairwise tests: control $\neq 2=4=$ $8 \mathrm{~m}$ for both partial and complete clearings). The PCOs showed that the cover of turf and foliose algae typically were associated with disturbances, whereas crusts were associated with canopy cover (controls plots) (Fig. 2). Results for fucoids, however, were less clear-cut. Fucoids were negatively associated with control plots in Jur and Mar (Fig. 2B,C); this pattern was less clear for Ham (Fig. 2B), while a weak positive association was observed at Kal (Fig. 2A; this effect was likely due to very low abundances of fucoids on these reefs, see also Fig. 3 and Section 4.1).

Overall, the cover of turfs increased after disturbance regardless of extent (pairwise tests: control $<2=4=8 \mathrm{~m}$; Table 2, Fig. 3) and intensity (In, p = 0.0001; Table 2, Fig. 3). Differences among levels of disturbance extent depended on disturbance intensity $(\mathrm{Ex} \times \mathrm{In}$, $\mathrm{p}=0.0104$; pairwise tests: $\mathrm{Cc}<2=4=8 \mathrm{~m}$; $\mathrm{Cp}<2=4=8 \mathrm{~m}$; Table 2), but this interaction reflected a lack of differences between disturbance controls $(\mathrm{Cc}=\mathrm{Cp})$ and differences among partial and complete disturbances. Turf cover also differed significantly among locations, being particularly high at Kal (Lo: $\mathrm{p}=0.0001$; Table 2, Fig. 3; pairwise tests: Ham = Jur < Mar < Kal). Finally, differences between partial and complete clearings depended on location; Kal showed a large increase in turf cover between the control and the partial clearings, whereas the 3 southern sites had large increases between the partial and the complete clearings ( $\mathrm{Lo} \times \mathrm{In}, \mathrm{p}=0.0427$; pairwise tests: Ham, Mar, Jur: $\mathrm{P}<\mathrm{C}_{i}$ Kal: $\mathrm{P}=\mathrm{C}_{i}$ Table 2).

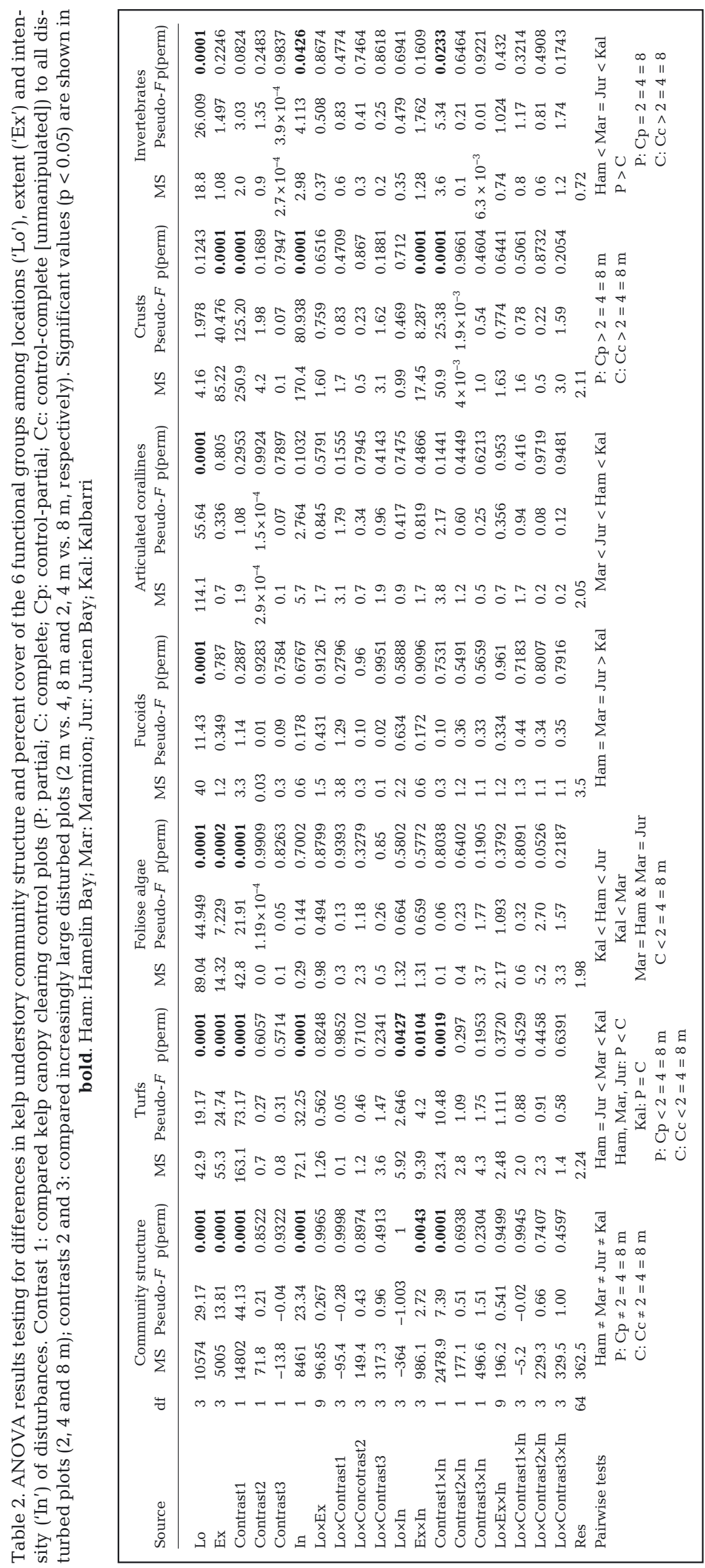



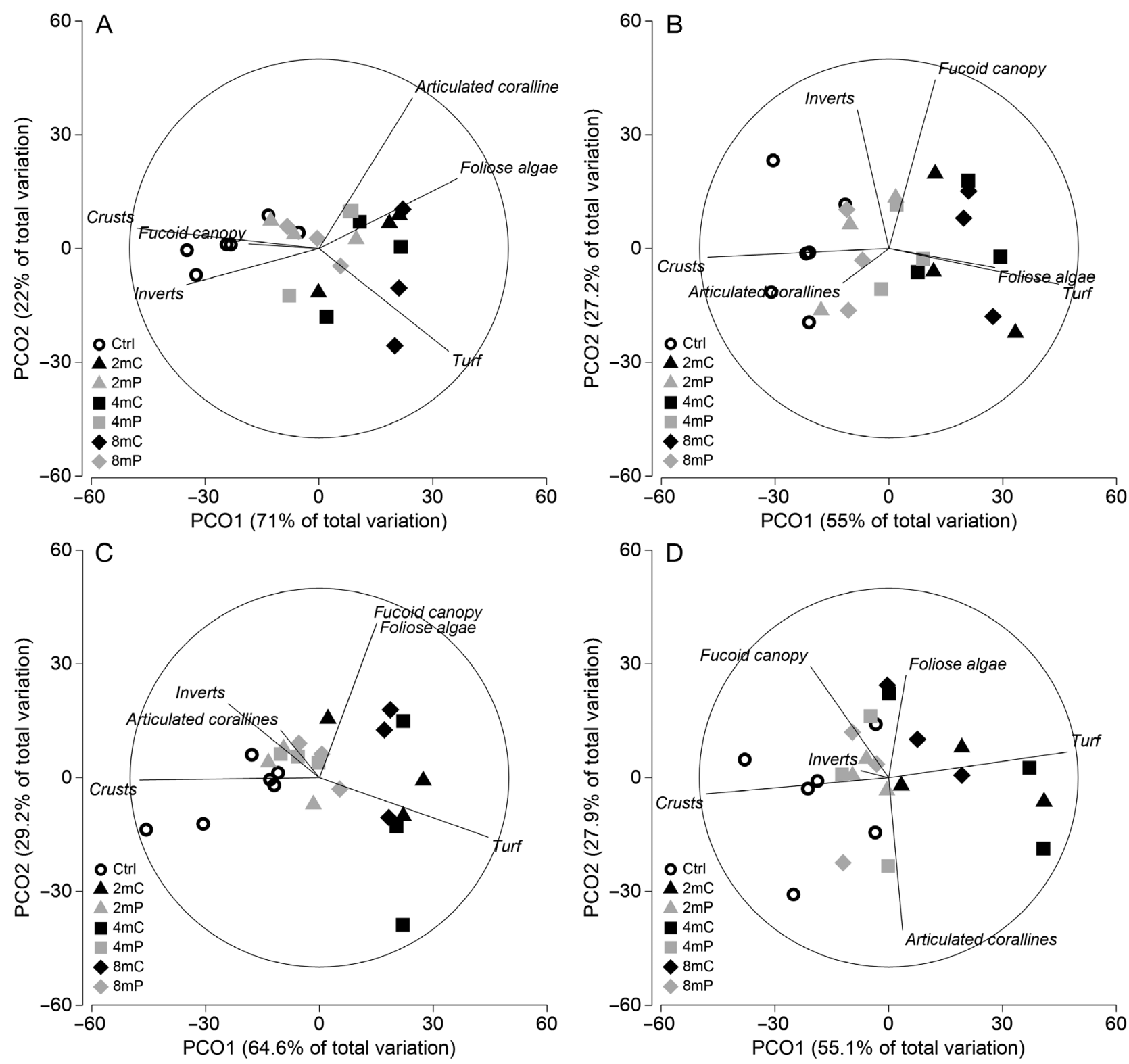

Fig. 2. Principal coordinates ordination of community structure according to disturbance intensity (partial [P] vs. complete [C] clearings) and extent (2, 4 and 8 m) at (A) Kalbarri, (B) Jurien Bay, (C) Marmion and (D) Hamelin Bay. Controls are unmanipulated plots with intact kelp canopies (here pooling the different controls set up separately for partial and complete clearings)

Similar to turfs, the cover of foliose algae increased overall in disturbed plots relative to controls (Table 2, Fig. 3). The cover of foliose algae also differed among locations, being much lower at Kal than the other locations (Lo: $p=0.0001$; Table 2, Fig. 3). However, in contrast to turfs, the cover of foliose algae was similar between the different disturbance intensities.

The cover of fucoids was, as for foliose algae, much lower at Kal than at the other locations (Lo, p = 0.0001; Table 2, Fig. 3). This result was reflected in the PERMDISP analysis which showed significant differences in the magnitude of variation of their cover among locations (Lo: $p=0.0001$; Table 3). Graphical analysis suggested that in Mar and Jur, fucoids had higher cover in the complete clearings compared to control plots (irrespective of extent, cover values in complete clearings were more than twice the values of unmanipulated controls, see Fig. 3). However, due to high variability (and lack of disturbance effects at Ham and Kal), these locationspecific differences were not statistically significant (Table 2). 

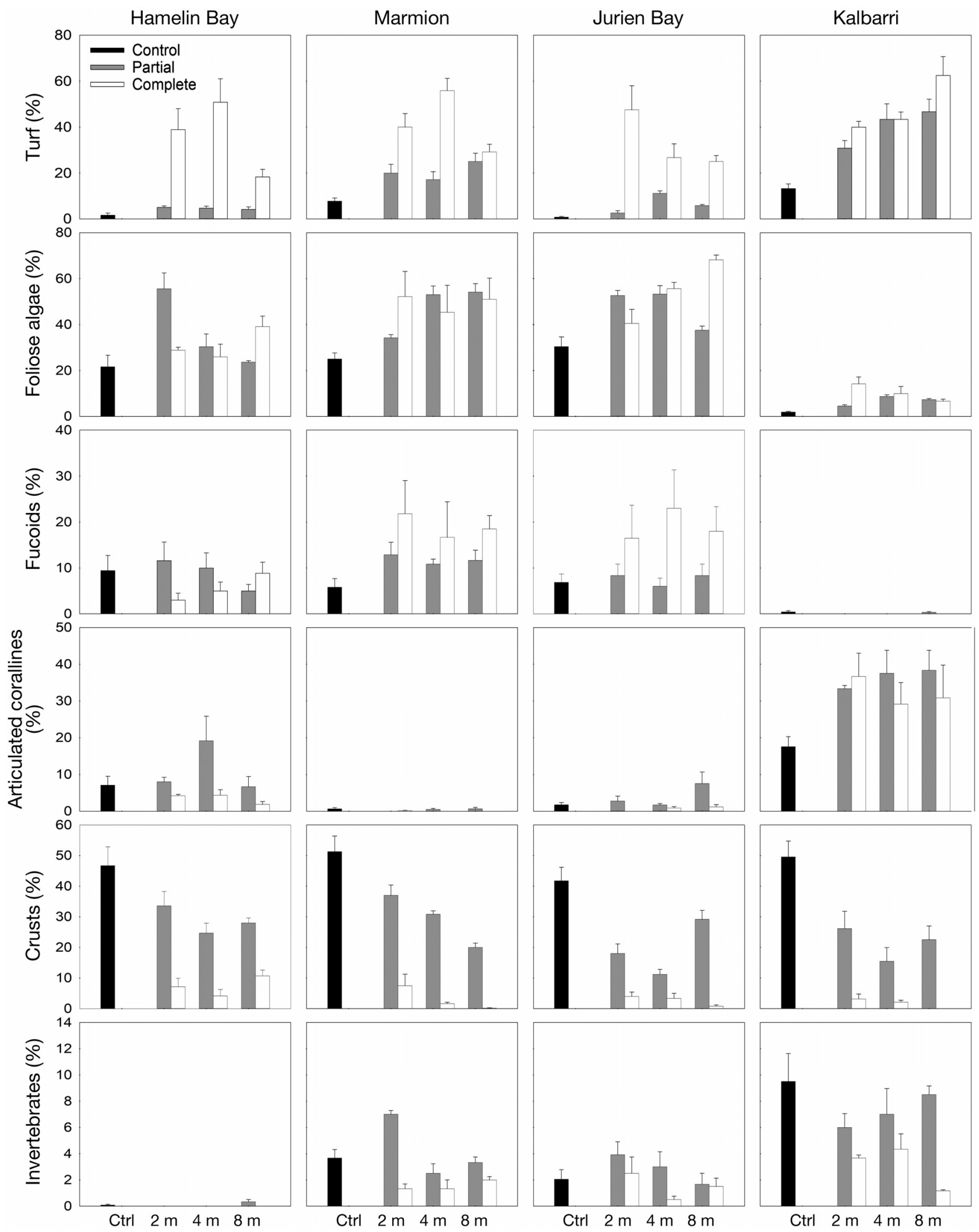

Fig. 3. Mean (+SE) percent cover of the 6 functional groups 8 mo after disturbances of varying intensity (partial vs. complete clearings) and extent $(2,4$ and $8 \mathrm{~m})$; controls are unmanipulated plots with intact kelp canopies (here pooling the different controls set up separately for partial and complete clearings) 
Table 3. PERMDISP results, testing for variances homogeneity in kelp understory community structures and the percent cover of the 6 functional kelp understory groups among locations ('Lo'), extent ('Ex') and intensity ('In') of disturbances. Significant values $(\mathrm{p}<0.05)$ are shown in bold

\begin{tabular}{|c|c|c|c|c|c|c|c|c|c|c|c|c|c|c|c|}
\hline \multirow[t]{2}{*}{ Source } & \multirow[t]{2}{*}{ df } & \multicolumn{2}{|c|}{$\begin{array}{l}\text { Community } \\
\text { structure }\end{array}$} & \multicolumn{2}{|c|}{ Turfs } & \multicolumn{2}{|c|}{ Foliose algae } & \multicolumn{2}{|c|}{ Fucoids } & \multicolumn{2}{|c|}{$\begin{array}{l}\text { Articulated } \\
\text { corallines }\end{array}$} & \multicolumn{2}{|c|}{ Crusts } & \multicolumn{2}{|c|}{ Invertebrates } \\
\hline & & $F$ & $\mathrm{p}($ perm $)$ & $F$ & $\mathrm{p}($ perm $)$ & $F$ & $\mathrm{p}($ perm $)$ & $F$ & $\mathrm{p}($ perm $)$ & $F$ & $\mathrm{p}($ perm $)$ & $F$ & $\mathrm{p}($ perm $)$ & $F$ & $\mathrm{p}($ perm $)$ \\
\hline Lo & 3 & 2.2167 & 0.1242 & 0.689 & 0.6310 & 2.021 & 0.1175 & 10.926 & 0.0001 & 7.275 & 0.0003 & 1.622 & 0.1952 & 14.125 & 0.0001 \\
\hline Ex & 3 & 3.1378 & 0.0606 & 1.920 & 0.1332 & 0.632 & 0.6274 & 0.642 & 0.6174 & 1.237 & 0.5033 & 6.244 & 0.0008 & 0.710 & 0.5664 \\
\hline In & 1 & 13.085 & 0.0023 & 2.321 & 0.1320 & 0.234 & 0.6254 & 3.036 & 0.0931 & 2.042 & 0.2350 & 19.012 & 0.0002 & 2.051 & 0.1541 \\
\hline
\end{tabular}

The cover of articulated corallines also differed among locations, being much higher at Kal than the 3 southern locations (Lo, $\mathrm{p}=0.0001$; Table 2, Fig. 3; pairwise tests: Mar < Jur < Ham < Kal). At the only location where articulated corallines were relatively common (i.e. $16 \%$ cover in control plots in Kal; Fig. $3)$, their cover was twice as high in disturbed plots, irrespective of disturbance intensity or extent (Fig. 3). However, as for fucoids, no significant effects were detected in the statistical analysis (Table 2), most likely because of differences among locations.

In contrast to the other understory groups, crusts did not vary between locations (Lo: $\mathrm{p}=0.1243$; Table 2 ), and responded consistently to disturbances. Thus, crusts dominated the understory community at all undisturbed control plots (mean cover $\sim 47 \%$, Ex: $\mathrm{p}=$ 0.0001; Table 2, Fig. 3) and had significantly higher cover $(21 \%$ more) in partial than complete clearings (In, p = 0.0001; Table 2, Fig. 3). As in the other functional groups, the cover of crusts did not vary between plot sizes (pairwise tests: control $>2=4=8 \mathrm{~m}$ ). In addition, PERMDISP analysis documented differences in the magnitude of variation in crust cover among disturbances of varying extent and intensity (Table 3).

Finally, we found that the cover of sessile invertebrates was lower in complete than partial clearings (In: $p=0.0426$; Table 2, Fig. 3). Differences between control plots and larger gap sizes depended on the level of disturbance intensity (Table 2). We also found that the cover of sessile invertebrates differed widely among locations, increasing along the temperature gradient by 2 orders of magnitude, from ca. $0.08 \%$ in Ham to ca. $8 \%$ in Kal (Lo: p $=0.0001$; Table 2, Fig. 3; pairwise tests: Ham $<$ Mar $=$ Jur $<\mathrm{Kal}$ ).

\section{DISCUSSION}

Using identical clearing experiments in kelp forests along a latitudinal gradient, we demonstrated that disturbance intensity (complete versus partial canopy removal) had much greater effects on understory communities than disturbance extent $(2,4$ or $8 \mathrm{~m}$ diameter impact). Thus, although we found strong effects between undisturbed control plots and disturbed plots, we found no major differences in understory communities associated with different spatial scales of disturbances. Irrespective of location, turfs and encrusting algae responded consistently to disturbance along the ocean climate gradient, increasing and decreasing in cover, respectively, in response to increasing disturbance regimes. By contrast, the 4 other understory functional groups showed more complex, locationdependent responses to disturbance intensity, possibly linked to their relative initial abundances at different latitudes.

\subsection{Regional-scale drivers and regional modification of disturbance effects}

Broad-scale climatic and oceanographic drivers, such as temperature, day length and ocean currents, affect the structure and functioning of kelp forests and associated communities (Connell \& Irving 2008, Wernberg et al. 2010, 2016a, Tuya et al. 2011). With the exception of temperature, our 4 widely separated locations were characterised by similar types of kelp forests in terms of percent cover and kelp density, with relatively similar kelp sizes and morphologies, as well as relatively similar environmental conditions (e.g. depth, nutrients, water clarity and wave exposure; Wernberg et al. 2010, 2011). Still, we found surprisingly different understory communities. For example, the northern location (Kal, warm) had much less foliose and fucoid algae, but more sessile invertebrates and articulated coralline algae compared to the southern location (Ham, cool), which had virtually no sessile invertebrates. These differences could likely be caused by different temperature regimes and different large-scale oceanographic processes that un- 
derpin distinct biogeographical regions (Wernberg et al. 2013b). For example, Kal is likely too warm for some species, such as the common fucoid Scytothalia dorycarpa and the foliose red alga Pterocladia lucida (Smale \& Wernberg 2013, Coleman \& Wernberg 2017), both of which were common in southern locations. Furthermore, articulated coralline algae were only found in very low abundances at the 2 mid regions (Mar and Jur). Importantly, these regional differences are in accordance with the (lack of) capacity of local understory communities to respond to disturbances, particularly for groups with limited propagule and dispersal traits. For example, the absence of invertebrates in the intact kelp forest at Ham, articulated corallines at Mar and Jur and fucoids at Kal resulted in no detectable effects of kelp clearing on these groups at these locations, possibly because there were simply too few propagules within the kelp forest to respond to the manipulated disturbances. By contrast, although turf forming algae were only found in very low background densities, high dispersal and rapid colonization traits (Hay 1981, Wernberg 2006, Wernberg \& Connell 2008, Antoniadou et al. 2010, Wernberg et al. 2016a) still allowed turfs to respond rapidly to perturbation and colonize disturbed plots. Thus, we highlight that any responses to disturbances (cf. sections below) should be interpreted within the context of the existing local understory community (species pool) and their dispersal and colonization traits.

\subsection{Local-scale disturbance effects: functional groups expected to increase following kelp removal}

We hypothesized that in our system, most algae that are smaller than kelp are often light-limited and sensitive to abrasion and whiplash from kelp fronds, and therefore will increase in cover following kelp removals. In support of this hypothesis, after 8 mo we found consistent density-dependent promotion of filamentous turfs associated with kelp loss across all locations: complete removal of kelp canopies resulted in a ca. $30 \%$ increase in turf cover and partial canopy loss also increased turfs, but to a lesser extent. Previous studies have shown that increases in resource availability, such as light, nutrients and space, promote rapid colonization by turf (Johnson \& Mann 1993, Worm et al. 2001, Connell 2005, Wernberg 2006, Russell 2007, Antoniadou et al. 2010). However, in contrast to our findings, and those of Wernberg \& Connell (2008) in South Australia where turfs also increased in partial clearings, turfs only increased after complete kelp removal in Tasmania (Flukes et al. 2014). Our results help reconcile these discrepancies, because we found that turfs at the 'warm' location (Kal) increased following any disturbance regime, whereas at the 'cool' location (Ham), increases only occurred following full disturbances (as in Flukes et al. 2014). The apparent greater expansion potential of turfs at warmer locations could be related to higher metabolic activity. Alternatively, differences between studies could be related to initial canopy density and/or to kelp morphology and composition (Kennelly 1989, FowlerWalker et al. 2005, 2006, Layton et al. 2019), including kelp surface area/volume ratio and measures of stipe width, which influence light penetration and whiplash from fronds.

Foliose algae also increased following kelp removal, but generally much less than turf algae, and without any density- or scale-dependent effects. Like turfs, foliose algae generally require high light conditions and available space and can be negatively affected by kelp abrasion (Toohey et al. 2004, Wernberg et al. 2005). However, the relatively small effect sizes, compared to turfs, could be due to generally lower colonization, slower growth, mismatch with reproductive season, increased competition from the faster responding turfs or the potential of foliose algae to photo-acclimatize under canopies (Toohey et al. 2004), reducing the net benefit of change in canopy cover. Although the duration of our experiment captures the main seasonal dynamics of Australian kelp forests (Wernberg \& Goldberg 2008), a longer duration of the experiment could have resulted in a stronger effect on this functional group. Furthermore, foliose algae is a very broad functional group, which could include both high-light and lowlight tolerant species (Wernberg et al. 2005).

In contrast to turfs and foliose algae, fucoids and articulated corallines were not significantly affected by disturbances, possibly because they only occurred at low or variable initial cover at some locations (and, hence, these statistical tests had low power). Thus, at 2 locations where fucoids were common (Mar and Jur), covers appeared to be higher in cleared plots (Fig. 3), despite high variability between reefs obscured the tendency of fucoids to follow the same patterns as other light-limited functional groups (Flukes et al. 2014). The lack of a positive response of fucoids to disturbances is unlikely to have been a consequences of mismatch with reproductive timing, as many common fucoids on this coastline have peak reproduction and recruitment between late autumn 
and early spring (Kendrick \& Walker 1994, Andrews et al. 2014). At the warmest location, the lack of response could partly be explained by low propagule supply (there were no fucoids in the control plots) and partly be related to competition from rapidly colonizing turfs. Other studies have shown rapid colonization of turf into disturbed plots and subsequent inhibition of fucoid settlement, survival and growth (Isæus et al. 2004, Wernberg 2006). It is, of course, possible that fucoids, over time, eventually would establish into these plots (Edwards 1998, Worm et al. 2001, Eriksson \& Johansson 2003). Similarly, articulated corallines did not show any response to disturbances, although at Kal, the only location with a relatively large cover of this functional group in control plots (Wernberg et al. 2011), articulated corallines appeared to increase following kelp removals (Fig. 3). Inhibition of articulated corallines by kelps has previously been reported from South Australia (Melville \& Connell 2001, Irving \& Connell 2006a).

\subsection{Local-scale disturbance effects: functional groups expected to be inhibited by kelp removal}

We hypothesized that functional groups with low or no light requirements would be negatively affected by kelp removals, because they grow slowly, which result in poor competitive abilities compared to more light-dependent and fast-growing species facilitated by kelp removals. In support of this hypothesis, we found that encrusting algae and sessile invertebrates were negatively affected by kelp removals. Encrusting algae showed the clearest spatially consistent pattern, being a dominant understory space occupier in all control plots across the latitudinal gradient. Across the 4 regions, crusts became less abundant due to overgrowth, with increasing disturbance regimes from partial to complete kelp removal. Positive associations between crusts and kelps have been described from several Ecklonia radiata studies (Melville \& Connell 2001, Irving \& Connell 2006b, Wernberg et al. 2011, 2013a, Flukes et al. 2014), and experiments have documented that kelps facilitate crusts by providing shade and decreasing sedimentation, as well as by reducing competition from other seaweeds (e.g. turfs and foliose algae) through abrasion, which crusts resist (Kennelly 1989, Irving et al. 2004, Toohey et al. 2004, Connell 2005). However, patterns of inhibition were less clear for sessile invertebrates. Sessile invertebrates appeared to be inhibited by kelp at the warmest location (Kal), the only location where invertebrates were relatively common in control plots. Like crusts, sessile invertebrates, in particular filter-feeders (i.e. sponges, ascidians and bryozoans), can be relatively resistant to abrasion but susceptible to sedimentation and increases in light following kelp removals (Kennelly 1991, Connell 2003, Lemloh et al. 2009, Smale \& Wernberg 2013). Furthermore, following kelp removals, sessile invertebrates could be more exposed to competition from foliose and turf algae and predation by mobile invertebrates and fish (Salter et al. 2010). Lack of similar inhibition following kelp removals from other locations could be attributed to low initial cover values, particularly evident for the coldest location (Ham).

\subsection{Conclusions}

We have demonstrated the importance of both regional and local drivers in controlling understory community structure of kelp forests in Western Australia and their short-term responses to a broad range of disturbances. On local scales, disturbance intensity generally had greater effects on the understory communities than disturbance extent. Functional groups with relatively high light requirements-particularly turfs, but also foliose algae, fucoid algae and articulated corallines-generally increased in cover following kelp loss. Conversely, less light-limited groups, such as encrusting algae and sessile invertebrates, typically were suppressed following kelp loss. The cover of turfs and encrusting algae varied across gradients in both disturbance intensity and extent (with density-dependent kelp inhibition and facilitation, respectively), with consistent effects across a broad-scale climatic gradient. However, for the other functional groups, responses to disturbances were modified by local conditions and, therefore, were less predictable. These broad-scale and density-dependent effects clearly illustrate how responses of kelp forests to disturbances are not 'binary' (either present or absent). This insight has consequences for both conservation and prospective restoration of damaged kelp forests, as it implies both the regional environmental context and kelp forest density needs to be considered against specific objectives (e.g. restoration success) for biodiversity and ecological function.

Acknowledgements. This research was supported by grants from the Australian Research Council to T.W. (DP555929, DP190100058). We acknowledge the camaraderie and friendship of Borat Sagdiyev during sampling. 


\section{LITERATURE CITED}

Anderson MJ, Diebel CE, Blom WM, Landers TJ (2005) Consistency and variation in kelp holdfast assemblages: spatial patterns of biodiversity for the major phyla at different taxonomic resolutions. J Exp Mar Biol Ecol 320: 35-56

Anderson MJ, Gorley RN, Clarke KR (2008) PERMANOVA+ for PRIMER: guide to software and statistical methods. PRIMER-E, Plymouth

Andrews S, Bennett S, Wernberg T (2014) Reproductive seasonality and early life temperature sensitivity reflect vulnerability of a seaweed undergoing range reduction. Mar Ecol Prog Ser 495:119-129

Antoniadou C, Voultsiadou E, Chintiroglou C (2010) Benthic colonization and succession on temperate sublittoral rocky cliffs. J Exp Mar Biol Ecol 382:145-153

Bell FW, Lamb EG, Sharma M, Hunt S, Anand M, Dacosta J, Newmaster SG (2016) Relative influence of climate, soils, and disturbance on plant species richness in northern temperate and boreal forests. For Ecol Manage 381: 93-105

Benedetti-Cecchi L, Airoldi L, Abbiati M, Cinelli F (1996) Estimating the abundance of benthic invertebrates: a comparison of procedures and variability between observers. Mar Ecol Prog Ser 138:93-101

* Benedetti-Cecchi L, Bertocci I, Vaselli S, Maggi E (2006) Temporal variance reverses the impact of high mean intensity of stress in climate change experiments. Ecology 87:2489-2499

Bennett S, Wernberg T, Connell SD, Hobday AJ, Johnson CR, Poloczanska ES (2016) The 'Great Southern Reef': social, ecological and economic value of Australia's neglected kelp forests. Mar Freshw Res 67:47-56

Byrnes JE, Reed DC, Cardinale BJ, Cavanaugh KC, Holbrook SJ, Schmitt RJ (2011) Climate-driven increases in storm frequency simplify kelp forest food webs. Glob Change Biol 17:2513-2524

Čada V, Morrissey RC, Michalová Z, Bače R, Janda P, Svoboda $M$ (2016) Frequent severe natural disturbances and non-equilibrium landscape dynamics shaped the mountain spruce forest in central Europe. For Ecol Manage 363:169-178

Cai W, Wang G, Santoso A, McPhaden MJ and others (2015) Increased frequency of extreme La Nina events under greenhouse warming. Nat Clim Chang 5:132-137

* Coleman MA, Wernberg T (2017) Forgotten underwater forests: the key role of fucoids on Australian temperate reefs. Ecol Evol 7:8406-8418

* Coleman MA, Vytopil E, Goodsell PJ, Gillanders BM, Connell SD (2007) Diversity and depth-related patterns of mobile invertebrates associated with kelp forests. Mar Freshw Res 58:589-595

Connell SD (2003) Negative effects overpower the positive of kelp to exclude invertebrates from the understorey community. Oecologia 137:97-103

Connell SD (2005) Assembly and maintenance of subtidal habitat heterogeneity: synergistic effects of light penetration and sedimentation. Mar Ecol Prog Ser 289:53-61

* Connell SD, Irving AD (2008) Integrating ecology with biogeography using landscape characteristics: a case study of subtidal habitat across continental Australia. J Biogeogr 35:1608-1621

Cox LE, Hart JL, Dey DC, Schweitzer CJ (2016) Composition, structure, and intra-stand spatial patterns along a disturbance severity gradient in a Quercus stand. For Ecol Manage 381:305-317

de Bettignies T, Wernberg T, Lavery PS, Vanderklift MA, Mohring MB (2013) Contrasting mechanisms of dislodgement and erosion contribute to production of kelp detritus. Limnol Oceanogr 58:1680-1688

* de Bettignies T, Wernberg T, Lavery PS, Vanderklift MA, Gunson JR, Symonds G, Collier N (2015) Phenological decoupling of mortality from wave forcing in kelp beds. Ecology 96:850-861

Denny M (1995) Predicting physical disturbance: mechanistic approaches to the study of survivorship on waveswept shores. Ecol Monogr 65:371-418

* Diaz-Pulido G, McCook LJ, Dove S, Berkelmans R and others (2009) Doom and boom on a resilient reef: climate change, algal overgrowth and coral recovery. PLOS ONE 4:e5239

*Dudgeon S, Petraitis PS (2001) Scale-dependent recruitment and divergence of intertidal communities. Ecology 82: 991-1006

*Edgar GJ, Barrett NS, Morton AJ, Samson CR (2004) Effects of algal canopy clearance on plant, fish and macroinvertebrate communities on eastern Tasmanian reefs. J Exp Mar Biol Ecol 312:67-87

* Edwards MS (1998) Effects of long-term kelp canopy exclusion on the abundance of the annual alga Desmarestia ligulata (Light F). J Exp Mar Biol Ecol 228:309-326

Englund G, Cooper SD (2003) Scale effects and extrapolation in ecological experiments. Adv Ecol Res 33: $161-213$

Eriksson BK, Johansson G (2003) Sedimentation reduces recruitment success of Fucus vesiculosus (Phaeophyceae) in the Baltic Sea. Eur J Phycol 38:217-222

F Farrell TM (1989) Succession in a rocky intertidal community the importance of disturbance size and position within a disturbed patch. J Exp Mar Biol Ecol 128: $57-74$

Flukes EB, Johnson CR, Wright JT (2014) Thinning of kelp canopy modifies understory assemblages: the importance of canopy density. Mar Ecol Prog Ser 514:57-70

Fowler-Walker MJ, Gillanders BM, Connell SD, Irving AD (2005) Patterns of association between canopy-morphology and understorey assemblages across temperate Australia. Estuar Coast Shelf Sci 63:133-141

*Fowler-Walker MJ, Wernberg T, Connell SD (2006) Differences in kelp morphology between wave sheltered and exposed localities: Morphologically plastic or fixed traits? Mar Biol 148:755-767

*Gagnon P, Himmelman JH, Johnson LE (2003) Algal colonization in urchin barrens: defense by association during recruitment of the brown alga Agarum cribrosum. J Exp Mar Biol Ecol 290:179-196

* Gaylord B, Reed DC, Raimondi PT, Washburn L, McLean SR (2002) A physically based model of macroalgal spore dispersal in the wave and current-dominated nearshore. Ecology 83:1239-1251

Granek E, Ruttenberg BI (2008) Changes in biotic and abiotic processes following mangrove clearing. Estuar Coast Shelf Sci 80:555-562

* Grime JP (1977) Evidence for the existence of three primary strategies in plants and its relevance to ecological and evolutionary theory. Am Nat 111:1169-1194

*Hay ME (1981) The functional morphology of turf-forming seaweeds: persistence in stressful marine habitats. Ecology 62:739-750 
IPCC (2014) Climate change 2014: synthesis report. Contribution of Working Groups I, II and III to the Fifth Assessment Report of the Intergovernmental Panel on Climate Change. IPCC, Geneva

Irving AD, Connell SD (2006a) Physical disturbance by kelp abrades erect algae from the understorey. Mar Ecol Prog Ser 324:127-137

Irving AD, Connell SD (2006b) Predicting understorey structure from the presence and composition of canopies: an assembly rule for marine algae. Oecologia 148:491-502

Irving AD, Connell SD, Elsdon TS (2004) Effects of kelp canopies on bleaching and photosynthetic activity of encrusting coralline algae. J Exp Mar Biol Ecol 310:1-12

Isæus M, Malm T, Persson S, Svensson A (2004) Effects of filamentous algae and sediment on recruitment and survival of Fucus serratus (Phaeophyceae) juveniles in the eutrophic Baltic Sea. Eur J Phycol 39:301-307

Johnson CR, Mann KH (1993) Rapid succession in subtidal understorey seaweeds during recovery from overgrazing by sea urchins in Eastern Canada. Bot Mar 36:63-77

Kendrick GA, Walker DI (1994) Role of recruitment in structuring beds of Sargassum spp. (Phaeophyta) at Rottnest Island, Western Australia. J Phycol 30:200-208

Kennelly SJ (1987a) Physical disturbances in an Australian kelp community. I. Temporal effects. Mar Ecol Prog Ser 40:145-153

Kennelly SJ (1987b) Physical disturbances in an Australian kelp community. II. Effects on understorey species due to differences in kelp cover. Mar Ecol Prog Ser 40:155-165

Kennelly SJ (1989) Effects of kelp canopies on understorey species due to shade and scour. Mar Ecol Prog Ser 50: 215-224

Kennelly SJ (1991) Caging experiments to examine the effects of fishes on understorey species in a sublittoral kelp community. J Exp Mar Biol Ecol 147:207-230

Kirkman H (1989) Growth, density and biomass of Ecklonia radiata at different depths and growth under artificial shading off Perth, Western Australia. Aust J Mar Freshwater Res 40:169-178

Kordas RL, Harley CDG, O'Connor MI (2011) Community ecology in a warming world: the influence of temperature on interspecific interactions in marine systems. J Exp Mar Biol Ecol 400:218-226

Kramer K, Brang P, Bachofen H, Bugmann H, Wohlgemuth $\mathrm{T}$ (2014) Site factors are more important than salvage logging for tree regeneration after wind disturbance in Central European forests. For Ecol Manage 331:116-128

Layton C, Shelamoff V, Cameron MJ, Tatsumi M, Wright JT, Johnson CR (2019) Resilience and stability of kelp forests: the importance of patch dynamics and environment-engineer feedbacks. PLOS ONE 14:e0210220

* Lemloh ML, Fromont J, Brümmer F, Usher KM (2009) Diversity and abundance of photosynthetic sponges in temperate Western Australia. BMC Ecol 9:4

Ling SD (2008) Range expansion of a habitat-modifying species leads to loss of taxonomic diversity: a new and impoverished reef state. Oecologia 156:883-894

Lison de Loma T, Harmelin-Vivien M, Naim O, Fontaine MF (2000) Algal food processing by Stegastes nigricans, an herbivorous damselfish: differences between an undisturbed and a disturbed coral reef site (La Réunion, Indian Ocean). Oceanol Acta 23:793-804

McCabe DJ, Gotelli NJ (2000) Effects of disturbance frequency, intensity, and area on assemblages of stream macroinvertebrates. Oecologia 124:270-279
Melville AJ, Connell SD (2001) Experimental effects of kelp canopies on subtidal coralline algae. Austral Ecol 26: 102-108

Norkko A, Rosenberg R, Thrush SF, Whitlatch RB (2006) Scale- and intensity-dependent disturbance determines the magnitude of opportunistic response. J Exp Mar Biol Ecol 330:195-207

* Oliver ECJ, Burrows MT, Donat MG, Sen Gupta A and others (2019) Projected marine heatwaves in the $21^{\text {st }}$ century and the potential for ecological impact. Front Mar Sci 6: 734

* Pascual M, Guichard F (2005) Criticality and disturbance in spatial ecological systems. Trends Ecol Evol 20:88-95

*Petraitis PS, Dudgeon SR (1999) Experimental evidence for the origin of alternative communities on rocky intertidal shores. Oikos 84:239-245

*Petraitis PS, Latham RE (1999) The importance of scale in testing the origins of alternative community states. Ecology 80:429-442

Russell BD (2007) Effects of canopy-mediated abrasion and water flow on the early colonisation of turf-forming algae. Mar Freshw Res 58:657-665

Salter ZT, Harvey ES, Kendrick GA, Murray K (2010) The effect of kelp bed disturbance on the abundance and feeding behaviour of fishes on high-relief reefs. Mar Freshwat Behav Physiol 43:109-125

Schiel DR, Lilley SA (2007) Gradients of disturbance to an algal canopy and the modification of an intertidal community. Mar Ecol Prog Ser 339:1-11

Schiel DR, Lilley SA (2011) Impacts and negative feedbacks in community recovery over eight years following removal of habitat-forming macroalgae. J Exp Mar Biol Ecol 407:108-115

* Smale DA, Wernberg T (2009) Satellite-derived SST data as a proxy for water temperature in nearshore benthic ecology. Mar Ecol Prog Ser 387:27-37

Smale DA, Wernberg T (2013) Extreme climatic event drives range contraction of a habitat-forming species. Proc $\mathrm{R}$ Soc B 280:20122829

* Smale DA, Wernberg T (2014) Population structure of the purple sea urchin Heliocidaris erythrogramma along a latitudinal gradient in south-west Australia. J Mar Biol Assoc UK 94:1033-1040

Smale DA, Kendrick GA, Wernberg T (2010) Assemblage turnover and taxonomic sufficiency of subtidal macroalgae at multiple spatial scales. J Exp Mar Biol Ecol 384: 76-86

Sousa WP (1984) The role of disturbance in natural communities. Annu Rev Ecol Syst 15:353-391

Sousa WP (2001) Natural disturbance and the dynamics of marine benthic communities. In: Bertness MD, Gaines SD, Hay ME (eds) Marine community ecology. Sinauer Associates, Sunderland, MA, p 85-130

* Thakur MP, Berg MP, Eisenhauer N, van Langevelde F (2014) Disturbance-diversity relationships for soil fauna are explained by faunal community biomass in a salt marsh. Soil Biol Biochem 78:30-37

* Thrush SF, Dayton PK (2002) Disturbance to marine benthic habitats by trawling and dredging: implications for marine biodiversity. Annu Rev Ecol Syst 33:449-473

* Toohey B, Kendrick GA, Wernberg T, Phillips JC, Malkin S, Prince J (2004) The effects of light and thallus scour from Ecklonia radiata canopy on an associated foliose algal assemblage: the importance of photoacclimation. Mar Biol 144:1019-1027 
Tuya F, Wernberg T, Thomsen MS (2008) The spatial arrangement of reefs alters the ecological patterns of fauna between interspersed algal habitats. Estuar Coast Shelf Sci 78:774-782

Tuya F, Wernberg T, Thomsen MS (2009) Colonization of gastropods on subtidal reefs depends on density in adjacent habitats, not on disturbance regime. J Molluscan Stud 75:27-33

Tuya F, Vanderklift MA, Hyndes GA, Wernberg T, Thomsen MS, Hanson C (2010) Proximity to rocky reefs alters the balance between positive and negative effects on seagrass fauna. Mar Ecol Prog Ser 405:175-186

Tuya F, Wernberg T, Thomsen MS (2011) The relative influence of local to regional drivers of variation in reef fishes. J Fish Biol 79:217-234

Vanderklift MA, Kendrick GA (2004) Variation in abundances of herbivorous invertebrates in temperate subtidal rocky reef habitats. Mar Freshw Res 55:93-103

Vaselli S, Bertocci I, Maggi E, Benedetti-Cecchi L (2008) Effects of mean intensity and temporal variance of sediment scouring events on assemblages of rocky shores. Mar Ecol Prog Ser 364:57-66

Wernberg T (2006) Scale of impact determines early postdisturbance assemblage structure in subtidal Fucus beds in the Baltic Sea (Bornholm, Denmark). Eur J Phycol 41: 105-113

Wernberg T, Connell SD (2008) Physical disturbance and subtidal habitat structure on open rocky coasts: effects of wave exposure, extent and intensity. J Sea Res 59: 237-248

Wernberg T, Goldberg N (2008) Short-term temporal dynamics of algal species in a subtidal kelp bed in relation to changes in environmental conditions and canopy biomass. Estuar Coast Shelf Sci 76:265-272

Wernberg T, Kendrick GA, Phillips JC (2003) Regional differences in kelp-associated algal assemblages on temperate limestone reefs in south-western Australia. Divers Distrib 9:427-441

Editorial responsibility: Jean-Sébastien Lauzon-Guay, Dartmouth, Nova Scotia, Canada
Wernberg T, Kendrick GA, Toohey BD (2005) Modification of the physical environment by an Ecklonia radiata (Laminariales) canopy and implications for associated foliose algae. Aquat Ecol 39:419-430

*Wernberg T, Thomsen MS, Tuya F, Kendrick GA, Staehr PA, Toohey BD (2010) Decreasing resilience of kelp beds along a latitudinal temperature gradient: potential implications for a warmer future. Ecol Lett 13:685-694

Wernberg T, Thomsen MS, Tuya F, Kendrick GA (2011) Biogenic habitat structure of seaweeds change along a latitudinal gradient in ocean temperature. J Exp Mar Biol Ecol 400:264-271

*Wernberg T, Smale DA, Tuya F, Thomsen MS and others (2013a) An extreme climatic event alters marine ecosystem structure in a global biodiversity hotspot. Nat Clim Chang 3:78-82

* Wernberg T, Thomsen MS, Connell SD, Russell BD and others (2013b) The Footprint of continental-scale ocean currents on the biogeography of seaweeds. PLOS ONE 8: e80168

* Wernberg T, Bennett S, Babcock RC, de Bettignies T and others (2016a) Climate-driven regime shift of a temperate marine ecosystem. Science 353:169-172

Wernberg T, de Bettignies T, Bijo AJ, Finnegan P (2016b) Physiological responses of habitat-forming seaweeds to increasing temperatures. Limnol Oceanogr 61: 2180-2190

*Wernberg T, Coleman M, Babcock R, Bell S and others (2019) Biology and ecology of the globally significant kelp Ecklonia radiata. Oceanogr Mar Biol Annu Rev 57: 265-324

Wilby PR, Kenchington CG, Wilby RL (2015) Role of low intensity environmental disturbance in structuring the earliest (Ediacaran) macrobenthic tiered communities. Palaeogeogr Palaeoclimatol Palaeoecol 434:14-27

* Worm B, Lotze HK, Sommer U (2001) Algal propagule banks modify competition, consumer and resource control on Baltic rocky shores. Oecologia 128:281-293

Submitted: April 24, 2020; Accepted: July 23, 2020

Proofs received from author(s): September 25, 2020 